\title{
Wyzwania i zagrożenia modernizacyjne gospodarki wynikające $z$ podziału terytorialnego Polski na regiony
}

\author{
Ryszarda Bolonek
}

Celem niniejszego artykułu jest ustalenie zasadności i możliwości realizacji w Polsce postawionych przez UE zadań na lata 2014-2020, które dotycza: wzrostu wskaźnika zatrudnienia do $75 \%$ wśród osób $w$ wieku 18-64; wydatków na $B+R$ w wysokości $3 \%$ PKB, likwidacji wykluczenia spotecznego, budowy gospodarki opartej na wiedzy. Analiza wewnętrznych zagrożeń dla modernizacji w regionach wykazuje, że cele UE odpowiadaja potrzebom gospodarek regionalnych $w$ Polsce, które charakteryzują się bardzo niskim średnim naktadem na sferę $B+R$, niskim wskaźnikiem zatrudnienia, a także znaczna dywergencja rozwojowa w podregionach. A zatem polityka spójności jest dla polskich regionów szansq rozwoju. Zagrożenia makroekonomiczne nie byty przedmiotem analizy, jednak można wskazać niska stopę oszczędności wewnętrznych, a tym samym ograniczone możliwości inwestowania, stabości rozwiąań instytucjonalnych oraz fiskalnych. Zagrożenia makroekonomiczne oraz wewnatrzregionalne sa przewidywalne, natomiast trudno przewidzieć zagrożenia zewnętrzne - koniunkturalne, zwiazane z euro, niedoszacowanie do ambitnych zadań UE wysokości przyznanych funduszy itp.

Słowa kluczowe: cele Europa 2020, wyzwania i zagrożenia modernizacyjne gospodarki Polski, problemy strukturalne regionów

Nadesłany: 07.11.2012 | Zaakceptowany do druku: 14.12.2012

\section{Challenges and threats of the economy modernization as the result of territorial division into regions in Poland}

The aim of this paper is to investigate the possibilities of EU goals realization in Poland. The EU goals in 2014-2020 financial perspective are following: the rise of employment index to the $75 \%$ among persons aged 18-64, the rise of R\&D outlays to the level of $3 \%$ GDP, building knowledge society etc. Internal threats analysis joined with the economy modernization in the regions of Poland indicates the EU goals cover the needs for regional development. The regional economies in Poland are characterized by low level of employment, low expenditures on $R \& D$ and by the significant development divergence in the NUTS-4 units level. Therefore cohesion policy makes opportunities for regional development. Macroeconomic threats were not the clue of the analysis, however literature points: low level of internal savings, limited possibilities to invest, institutional and financial weaknesses. Internal threats are easier to foresee, but external, joined with the European funds, euro stability, economy cycle seems to be more risky.

Keywords: Europa 2020 objectives, the economy modernisation threats and challenges, structural problems of regions in Poland, external threats of modernization

Submitted: 07.11.2012 | Accepted: 14.12.2012

JEL: R120

* Dr Ryszarda Bolonek, Uniwersytet Ekonomiczny w Krakowie Adres do korespondencji: Uniwersytet Ekonomiczny w Krakowie, Katedra Ekonomii Stosowanej, ul. Rakowicka 27, 31-510 Kraków, e-mail: bolonekr@krakow.uek.pl. 


\section{Wstęp}

Pojęcie modernizacji, czyli unowocześnienia, może być rozważane pod wieloma względami, na przykład pod kątem modernizacji: technologicznej, strukturalnej, instytucjonalnej, ekologicznej, fiskalnej, badawczo-rozwojowej, zaś celem modernizacji może być wzrost, rozwój bądź spójność gospodarcza.

W świetle dokumentu Europa 2020. Strategia na rzecz inteligentnego $i$ zrównoważonego rozwoju sprzyjającego wtaczeniu społecznemu ${ }^{1}$ cele Unii Europejskiej na lata 2014-2020 dotyczą, między innymi, osiągnięcia wskaźnika zatrudnienia osób w wieku 20-64 lata na poziomie $75 \%$; osiągnięcia poziomu wydatków na $\mathrm{B}+\mathrm{R}$ w wysokości przekraczającej 3\% PKB; zmniejszenia liczby osób zagrożonych ubóstwem o $20 \mathrm{mln}$. Rozwój inteligentny należy rozumieć jako dążenie do gospodarki opartej na wiedzy ${ }^{2}$ i rozwój sprzyjający włączeniu społecznemu. Głównym celem jest zatem wspieranie gospodarki o wysokim poziomie zatrudnienia, który jednocześnie zapewniałby spójność społeczną i terytorialną.

Celem niniejszego artykułu jest ustalenie zasadności i możliwości realizacji w Polsce tak postawionych przez UE dążeń. Od razu nasuwają się wątpliwości, że gospodarka Polski jest zbyt słaba, by osiągnąć takie cele w okresie 7 lat.

W związku z tym można sformułować hipotezę, że największe zagrożenie dla modernizacji Polski stanowi niedostosowanie wysokości przyznanych funduszy europejskich do ambitnych zadań (ujętych w planie UE na lata 2014-2020) ze względu na różnice podstawowych wskaźników makroekonomicznych między UE 27 a Polską.

Pierwsza część artykułu będzie dotyczyć podstaw metodologicznych analizy, druga - charakterystyki wyzwań i zagrożeń dla gospodarki Polski w ujęciu regionalnym, zaś trzecia stanowi podsumowanie analizy.

\section{Region jako podmiot mezoekonomiczny}

Pojawienie się nowego podmiotu rozważań ekonomicznych, jakim jest region, stwarza problemy natury metodologicznej. Jeżeli założymy, że region jest ogniwem pośrednim między rozważaniami mikro- ekonomicznymi i makroekonomicznymi, to powstaje metodologiczna próżnia. W literaturze polskiej próbę wyodrębnienia szczebla mezoekonomicznego podjęli Cz. Bywalec, J. Gajda, M. Gorynia i Z. Hockuba. Traktują oni poziom mezoekonomiczny jako pośredni między makro- i mikroekonomicznym, odnosząc go do różnych działów i branż gospodarki, regionów i grup społecznych (Gajda, 1996, s. 12), struktur gospodarczych średniego szczebla, a więc w sektorach (działach i branżach) gospodarki, regionach, zorganizowanych grupach ludzkich (Bywalec, 1996, s. 21), w kontekście teorii struktury branży i paradygmatu J.S. Baina struktura - zachowanie - efektywność, czyli związki między strukturą rynku branżowego, postępowaniem (zachowaniem się) przedsiębiorstw i efektywnością (Gorynia, 1996, s. 26), zbioru zakładów (przedsiębiorstw) produkcyjnych i usługowych, który można wyróżnić ze względu na cechy: podobieństwa powiązań komplementarnych, skupienia przestrzennego (Zioło, 1996, s. 56). Jako narzędzia badawcze Cz. Bywalec (1996, s. 21) proponuje: metodę input-output, analizę czynnikową, metody analizy regionalnej (przestrzennej), metodykę badania struktur (podobieństwa, dynamiki itp.), zaś M. Gorynia - wykorzystanie ogólnej teorii systemów (1996, s. 28).

$\mathrm{W}$ związku z powyższym potrzebne jest przypomnienie podstawy metodologicznej, na której opiera się mikroekonomia.

Mikroekonomia zajmuje się badaniem zachowań indywidualnych uczestników gospodarki rynkowej (konsumentów, producentów, inwestorów, właścicieli ziemi itd.) oraz analizą rynków poszczególnych dóbr i usług (Pindyck i Rubinfeld, 1989, s. 3; Szczepaniec, 1996, s. 9). Rynki poszczególnych dóbr i usług dotyczą zatem poszczególnych dóbr i usług, takich jak samochody, wyroby naftowe, dobra komputerowe, a tym samym dotyczą branży motoryzacyjnej, naftowej, komputerowej. Nazwa mikroekonomii pochodząca od greckiego słowa mikros oznaczającego „mały” (Słownik wyrazów obcych PWN, s. 475) może być myląca, ponieważ firmy rynku motoryzacyjnego, naftowego czy komputerowego Stanów Zjednoczonych mogą przewyższać swoimi dochodami wysokość PKB niejednego kraju. Branżowy charakter analizy mikroekonomicznej nabiera dyskusyjnego znaczenia w okresie konieczności wyodrębnienia podstaw metodologicznych analizy 
mezoekonomicznej - regionalnej. Można zgodzić się z tezą, ze poziom mezoekonomiczny jest pośredni między rozważaniami mikro- i makroekonomicznymi. Jednak ograniczenie szczebla mezoekonomicznego do analizy branżowej pokrywa się $\mathrm{z}$ analizą mikroekonomiczną, trudno mieć bowiem wątpliwości co do faktu, że rynki poszczególnych dóbr i usług to rynki branżowe.

W tej sytuacji być może wyjściem z impasu metodologicznego jest traktowanie poziomu mezoekonomicznego jako analizy branżowej i procesów zachodzących na administracyjnym terytorium regionu w myśl koncepcji rozwoju terytorialnego F. Barca (place-based approach) (Barca, 2009). Trzeba jednak zauważyć, że ograniczenie analizy danej branży do terytorium regionu będzie miało mniejszy zasięg niż rynku tej branży w Polsce, który jest przecież rynkiem mikroekonomicznym. W tym kontekście wydaje się, że bardziej odpowiednią nazwą dla przekształceń mezoekonomicznych będzie „mikroekonomia terytorialna”.

Wielu naukowców próbuje określić mezoekonomiczny poziom rozważań przez przystosowanie makroekonomicznej teorii wzrostu dla potrzeb regionalnych. Przystosowanie teorii wzrostu i teorii rozwoju gospodarczego do poziomu regionalnego napotyka wiele trudności. Wprawdzie w literaturze przedmiotu wskazuje się na istnienie regionalnych teorii wzrostu, jednak są one oparte w znacznej części na modelach makroekonomicznych (Lucas, 1988; Romer, 1986; Fujita, Krugman i Venables, 1999; Sala-i-Martin, 1994; Barro i Sala-i-Martin 1995 i in.). Jak zauważają H. Armstrong, R. Vickerman (1995), adaptacja nowej teorii wzrostu endogenicznego do poziomu regionalnego, być może jest największym metodologicznym wyzwaniem. Dotychczasowe osiagnięcia w tej dziedzinie (Glaeser, 2000) budzą wiele wątpliwości teoretycznych (Roberts i Setterfield, 2007).

Być może w postępowaniu modernizacyjnym należałoby uwzględnić w większym, niż dotychczas, stopniu podmiot mezoekonomiczny, jakim jest region i jego zasoby, co w teorii wzrostu znajduje odniesienie do koncepcji regionalnego wzrostu endogenicznego (Jacobs, 1969; Romer, 1986; Lucas, 1988; Porter, 1990; Grossman i Helpman, 1991). W związku z trudnościami wyodrębnienia szczebla mezoeko- nomicznego proponuje się nazwę: „mikroekonomia i makroekonomia terytorialna".

Wobec trudności metodologicznych z wyodrębnieniem regionu jako szczebla pośredniego i w związku $\mathrm{z}$ tym wykorzystania specyficznych narzędzi analitycznych pozostaje analiza danych statystycznych oferowanych przez GUS.

W nomenklaturze GUS w Polsce występuje 6 regionów: centralny, południowy, wschodni, zachodnio-południowy, zachodnio-północny, północny; natomiast to, co dla GUS jest regionem, w UE traktowane jest jako makroregion, zaś województwo jako region. Jednak wykorzystywanie regionalnych i wojewódzkich danych statystycznych obliguje do korzystania $\mathrm{z}$ nazewnictwa GUS-u, tym bardziej że Eurostat je powtarza.

\section{Charakterystyka wyzwań i zagrożeń dla regionów Polski w perspektywie celów Europa 2020}

Podstawowe wyzwania i zagrożenia wobec modernizacji ujętej w podziale terytorialnym Polski na regiony wynikają z możliwości uzyskania zewnętrznych źródeł finansowania (funduszy unijnych, bezpośrednich inwestycji zagranicznych), stymulowania oszczędności wewnętrznych jako źródeł finansowania modernizacji oraz wewnętrznych barier rozwoju. Niektóre z wyzwań i zagrożeń zostały odzwierciedlone w tabeli 1 .

Niniejsza analiza została poświęcona zagrożeniom i wyzwaniom modernizacyjnym wynikającym z podziału Polski na regiony. Wobec tego zagrożenia makroekonomiczne i zagrożenia zewnętrzne wykraczają poza temat i nie będą przedmiotem szczegółowych rozważań. Jednak fakt, że determinują możliwości rozwoju regionalnego spowodował wyszczególnienie niektórych $\mathrm{z}$ nich $\mathrm{w}$ tabeli 1 .

W związku z powyższym analiza dotyczy w pierwszej części dywergencji dochodowej i płacowej w regionach i województwach, w części drugiej - struktury tworzenia wartości dodanej brutto $\mathrm{w}$ podziale na trzy sektory gospodarcze w ujęciu wojewódzkim oraz konfrontacji tworzenia WDB w Polsce ze specjalizacją Polski w ramach UE oraz tworzeniem wartości dodanej w UE. Trzecia część została poświęcona analizie wojewódzkiej struktury nakładów na $\mathrm{B}+\mathrm{R}$. Wprawdzie wybór trzech powyższych 


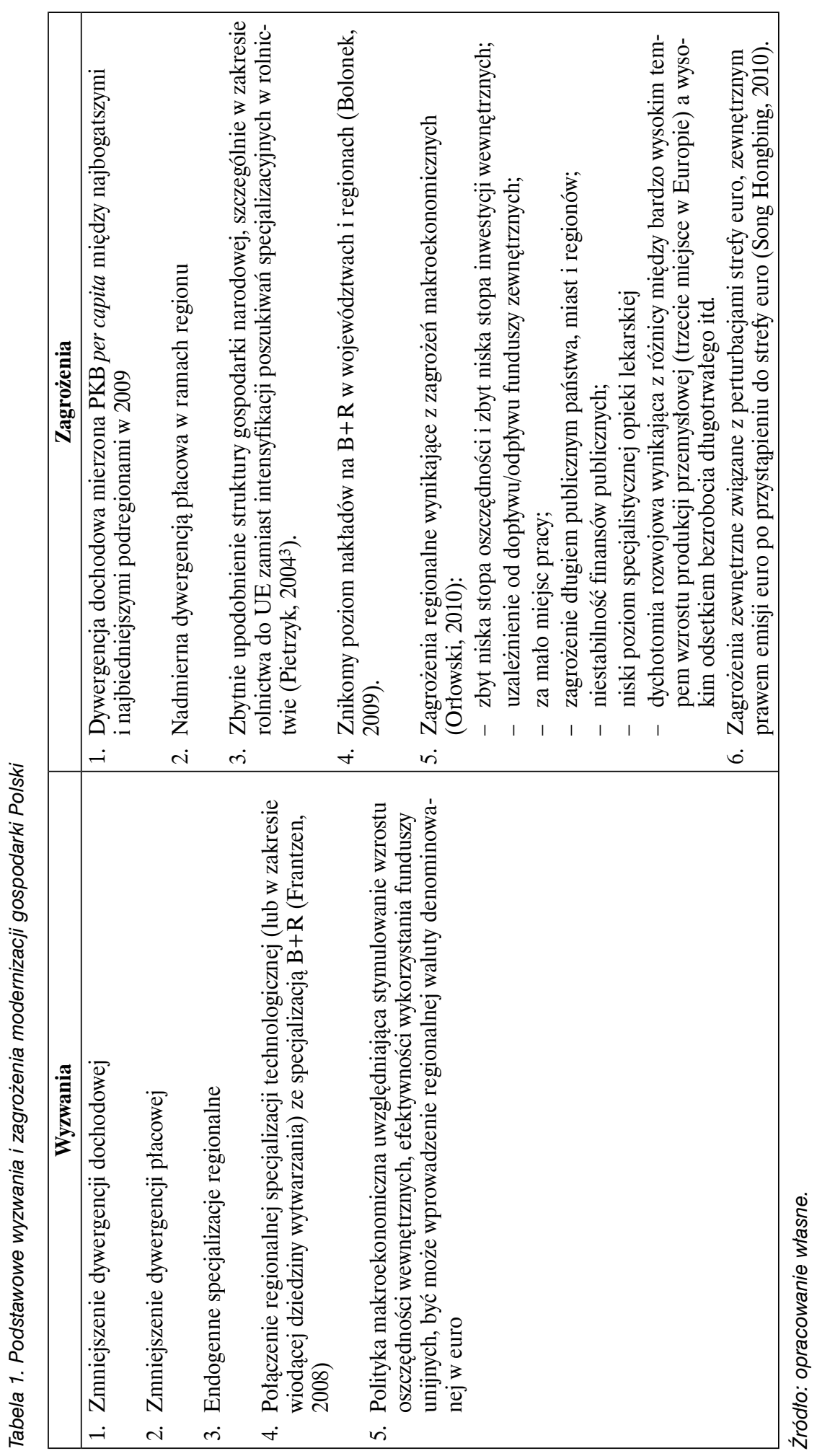


aspektów rozwoju regionalnego do analizy może być dyskusyjny, to jednak na ich podstawie można zorientować się co do skali rozbieżności rozwoju regionalnego.

\subsection{Dywergencja dochodowa w regionach i województwach}

Zmiany administracyjne z 2000 roku (Dz.U. Nr 58, poz. 685 z późn. zm.), polegające na wyodrębnieniu 6 regionów, a w ich ramach 16 województw, spowodowały, że w ramach regionów znalazły się obszary stosunkowo dobrze i bardzo słabo rozwiniete. $\mathrm{Z}$ tego powodu podział dochodów między regionami Polski, zwanymi w UE makroregionami, na poziomie NUTS-1 jest relatywnie równomierny z wyjątkiem wysokich dochodów regionu centralnego i niskich dochodów regionu wschodniego.

Dyspersja dochodowa zauważalna jest na poziomie województw, zwanych w UE regionami, na poziomie NUTS-2. Jednak dopiero na poziomie NUTS-3, zwanym w nomenklaturze GUS podregionami, ujawniają się znaczne dysproporcje rozwojowe.

Dyspersja dochodów w województwach jest znaczna, szczególnie w relacji centrum- peryferie, co znajduje swoje odzwierciedlenie w różnicach dochodów między dużymi miastami, będącymi centralnymi ośrodkami rozwoju województw a peryferiami województw. Zróżnicowanie PKB w województwach w 2009 roku przedstawia rysunek 1.

Jak wynika z rysunku 1, województwa, których poziom PKB jest najwyższy, to: mazowieckie, śląskie, wielkopolskie i dolnośląskie, natomiast najniższe poziomy PKB występują w województwach: podlaskim, opolskim, lubuskim i świętokrzyskim, przy czym podlaskie i świętokrzyskie należą do regionu wschodniego. Różnica mièdzy mazowieckim $(21,5 \%)$ a podlaskim $(2,3 \%)$ wynosi 19,2\% PKB Polski w 2008 roku $($ PKB Polski $=100)$.

Przyznane w budżecie UE na lata 2007-2013 fundusze dla Polski, przeznaczone na poprawienie spójności społecznogospodarczej obszaru UE (Pietrzyk, 2007), dały szansę na przyspieszony rozwój naszego kraju i zniwelowanie największych różnic gospodarczych między Polską a pozostałymi krajami Unii, jednak wydaje się, że nie spowodowały zmniejszenia dyspersji wewnątrzwojewódzkiej, co odzwierciedla tabela 2 .

Rysunek 1. PKB według województw w 2009 roku, w odsetkach

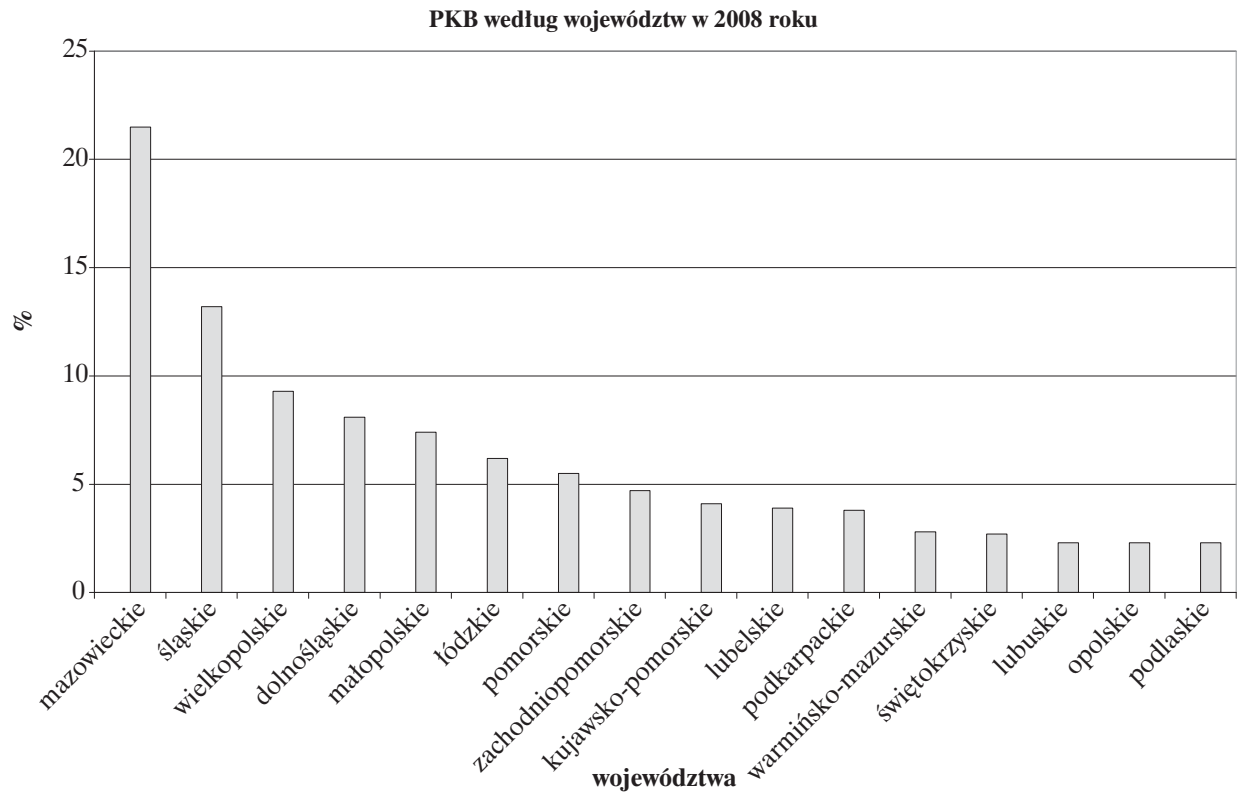

Źródło: Rocznik Statystyczny Województw 2010, GUS, Warszawa 2010, tabela II. Ważniejsze dane o województwach, s. 86-87. 


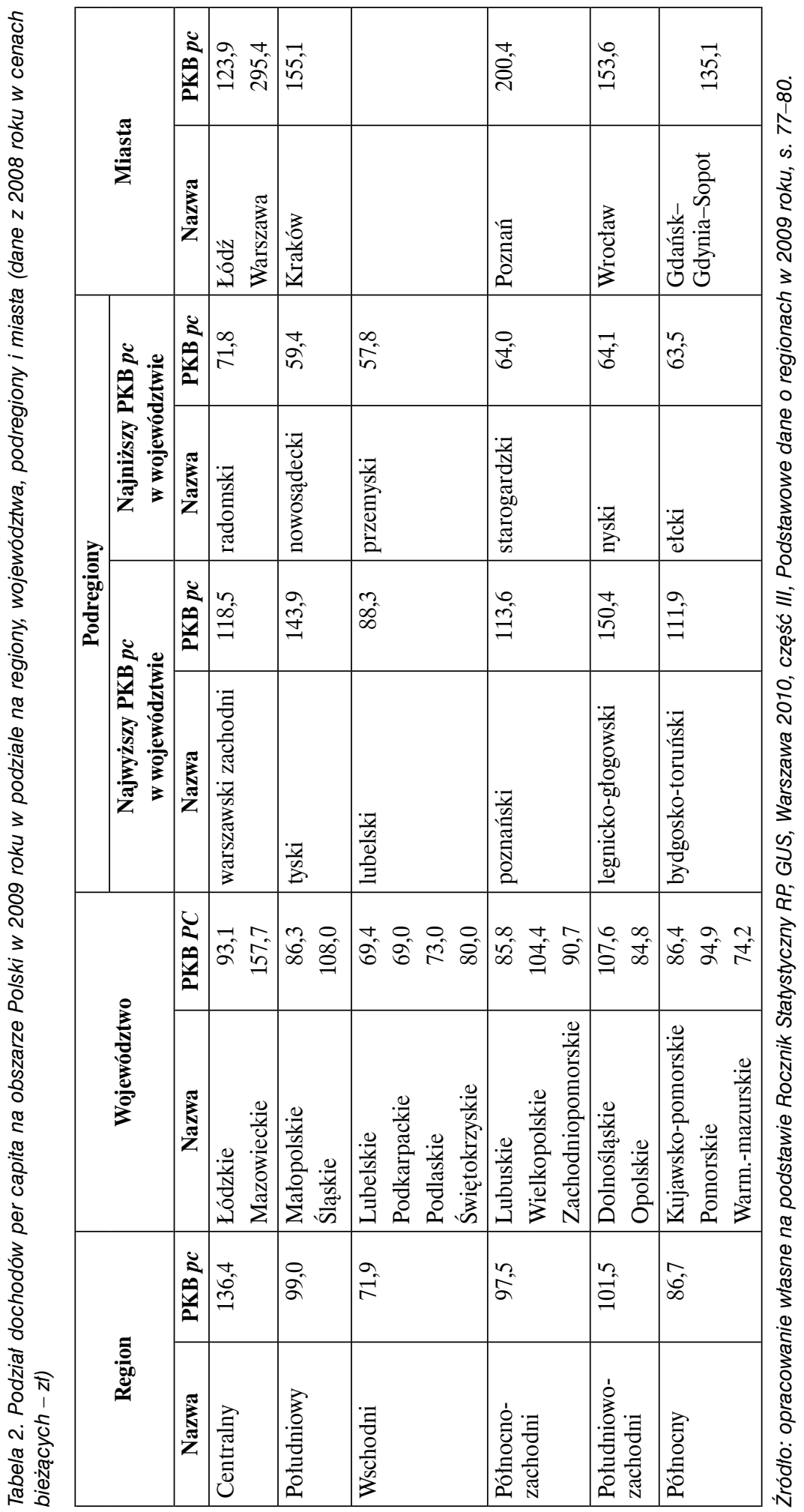


Jak wynika $\mathrm{z}$ tabeli 2 , regionem o najwyższym dochodzie per capita jest centralny, a najniższym - wschodni. Na poziomie województw zróżnicowanie w ramach regionów zwiększa się - najwyższe dochody per capita występują w województwach: mazowieckim, śląskim, dolnośląskim i wielkopolskim. Województwa najbiedniejsze to: podkarpackie, lubelskie, podlaskie, warmińsko-mazurskie.

Natomiast w podregionach zauważalny jest wzrost rozpiętości dochodowych między podregionami najbogatszymi i najbiedniejszymi danego regionu. I tak, w roku 2008 rozpiętość dochodowa mierzona PKB per capita $\mathrm{w}$ najbogatszym i najbiedniejszym podregionie regionu centralnego wynosiła odpowiednio 118,5 oraz 71,8 105,3. Jeszcze większy wzrost rozpiętości dochodowej można zauważyć w podregionach regionu południowego: 143,9 (tyski) - 59,3 (nowosądecki). Także w regionie południowo-zachodnim znaczna jest różnica w dochodach per capita między podregionem legnicko-głogowskim $(150,4)$ a nyskim $(64,1)$.

Wśród największych miast Polski najniższe dochody per capita występują w Lodzi.

Odnośnie do 2011 roku można stwierdzić, że mimo wzrostu konwergencji terytorialnej między Polską a Unią Europejską (Weresa, 2010) istnieje dywergencja wewnątrz regionów i województw najbardziej zauważalna w podregionach.

Przytoczenie różnic płacowych wewnątrz najbogatszych województw, do których należą mazowieckie i śląskie, ma na celu pogłębioną analizę różnic regionalnych. Różnice płacowe w województwie mazowieckim, śląskim i dolnośląskim przedstawione zostały w tabeli 3 .

Dysproporcje płac w województwie mazowieckim sa najwyższe w Polsce. Różnica między średnią płacą w Warszawie (4603 zł $=138,8 \%$ średniej krajowej) a innym podregionem tego województwa ostrołęcko-siedleckim $(2820 \quad \mathrm{zl}=85,1 \%$ średniej krajowej) wynosi 1783 zl, co stanowi 53,7\% średniej krajowej. Być może takie różnice płacowe są naturalną ekonomiczną konsekwencja rozwoju typu centrum-peryferie, jednakże w obliczu starań o dofinansowanie z Unii Europejskiej dla całego regionu potrzebna jest większa dbałość o cel dofinansowania, jakim pozostaje spójność ekonomiczna, w tym dochodowopłacowa.
Tabela 3. Zróżnicowanie płacowe $w$ podregionach województw najbogatszych w 2009 roku

\begin{tabular}{|l|c|c|}
\hline \multirow{2}{*}{\multicolumn{1}{|c|}{ Nazwa }} & \multicolumn{2}{c|}{$\begin{array}{c}\text { Przeciętne miesięczne } \\
\text { wynagrodzenia } \\
\text { brutto w 2009 r. }\end{array}$} \\
\cline { 2 - 3 } Polska & $\mathbf{3 ~ z l}$ & Polska 100 \\
\hline \multicolumn{1}{|c|}{ Mazowieckie } & $\mathbf{4 . 1 7 9}$ & $\mathbf{1 0 0 , 0}$ \\
\hline $\begin{array}{l}\text { Podregiony: } \\
\text { ciechanowsko-płocki }\end{array}$ & $\mathbf{1 2 6 , 1}$ \\
ostrołęcko-siedlecki & 2.820 & 98,2 \\
radomski & 2.911 & 85,1 \\
Warszawa & $\mathbf{4 . 6 0 3}$ & $\mathbf{1 3 8 , 8}$ \\
warszawski wschodni & 3.063 & 92,4 \\
warszawski zachodni & 3.496 & 105,5 \\
\hline Śląskie & $\mathbf{3 . 4 0 5}$ & $\mathbf{1 0 2 , 7}$ \\
Podregiony: & & \\
bielski & 3.054 & 92,1 \\
bytomski & 2.804 & 84,6 \\
częstochowski & 2.732 & 82,4 \\
gliwicki & 3.417 & 103,1 \\
katowicki & $\mathbf{4 . 0 9 0}$ & $\mathbf{1 2 3 , 4}$ \\
rybnicki & 3.502 & 105,7 \\
sosnowiecki & 3.269 & 98,6 \\
tyski & 2.933 & 88,5 \\
\hline Dolnośląskie & $\mathbf{3 . 2 9 5}$ & $\mathbf{9 9 , 4}$ \\
Podregiony: & & \\
jeleniogórski & 2.910 & 87,8 \\
legnicko-gtogowski & $\mathbf{3 . 8 7 9}$ & $\mathbf{1 1 7 , 0}$ \\
wałbrzyski & 2.872 & 86,6 \\
wrocławski & 2.812 & 84,8 \\
wrocław & 3.556 & 107,3 \\
\hline
\end{tabular}

Źródło: opracowanie własne na podstawie Rocznika Statystycznego Województw 2010, GUS, Warszawa 2010, tab. III, Wybrane dane o podregionach NUTS - 3 w 2009 roku, s. 114.

Zatem dopóty, dopóki Polska jest beneficjentem funduszy pomocowych z Unii Europejskiej na rzecz spójności gospodarczej, w polityce wojewódzkiej powinno się w większym stopniu zwracać uwagę na zmniejszenie różnic dochodowych, które mogą stać się barierą rozwoju, a przynajmniej uzyskania odpowiedniej pomocy w budżecie UE na kolejne lata 2014-2020.

Podobny problem może wkrótce dotyczyć podregionu katowickiego w województwie śląskim oraz podregionu Wrocławia w dolnośląskim. Sytuacja Wrocławia 
nie jest tak korzystna, jakby to wynikało $\mathrm{z}$ tabeli 2, ponieważ Wrocław jest, obok Krakowa, jednym z najbardziej zadłużonych miast w Polsce.

Potwierdzenie regionalnej dywergencji rozwojowej w Polsce stanowi mapa 1, opracowana w ramach Raportu Banku Swiatowego z 2009 roku.

Jak wynika $\mathrm{z}$ mapy, najwyższym tempem rozwoju w Polsce charakteryzują się obszary większych aglomeracji miejskich:

\subsection{Struktura tworzenia wartości dodanej brutto $w$ województwach}

Wśród województw Polski, pod względem wielkości wytwarzanej wartości dodanej brutto (WDB), przoduja typowo przemysłowe, takie jak: mazowieckie, śląskie, wielkopolskie, dolnośląskie, małopolskie i łódzkie.

W ujęciu regionalnym najwyższe poziomy WDB tworzą regiony centralny i południowy oraz po jednym województwie regionu północno-zachodniego (wielkopol-

\section{Mapa 1. Dystrybucja dochodów w Polsce mierzona wysokością PKB na metr kwadratowy}

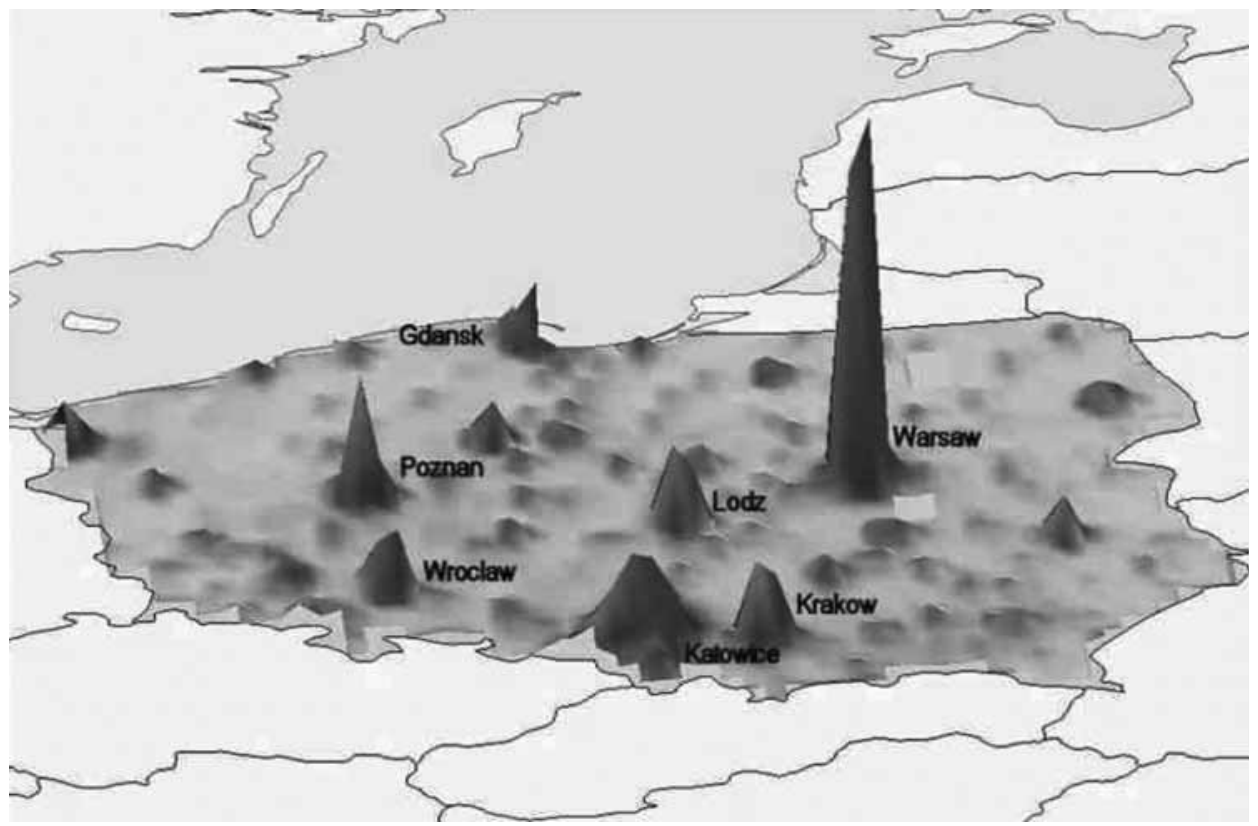

Źródło: I. Gill, Regional development policies: place-based or people centred?, za: World Bank GIS Laboratory, 9.10.2010; http://www.voxeu.org/index.php?q=node/5644 (24.11.2011).

Warszawy, Łodzi, Katowic, Krakowa, Poznania, Gdańska, Wrocławia i Szczecina, przy czym rozwój Warszawy jest kilkakrotnie wyższy od pozostałych miast.

Wynika z tego, że rozwój regionalny nie jest ani spójny, ani zrównoważony. W związku z tym problemem, a raczej wyzwaniem gospodarczym, pozostaje aktywizacja terenów poza większymi miastami.

Podsumowując, można stwierdzić dywergencję dochodową, szczególnie zauważalną na poziomie podregionów. Zróżnicowanie płac w najbogatszych w 2009 roku regionach potwierdza tę niekorzystną dysproporcję $\mathrm{w}$ podziale dochodów i stanowi poważną barierę rozwoju regionalnego. skie) i południowo-zachodniego (dolnośląskie). Mimo że upadający przemysł lekki województwa łódzkiego obniżył wielkość wytwarzanej WDB, to jednak lączna WDB tych 6 województw dała 733,6 mln zł w 2009 roku (w cenach bieżących) wobec wytworzonej WDB Polski o wartości 1,116 mln zł w tym samym roku. Tworzenie wielkości wartości dodanej brutto w województwach przedstawia rysunek 2 .

Łączna wielkość WDB pierwszych 6 województw stanowi 66\% wartości dodanej brutto Polski. A zatem pozostałe 10 województw wytwarza tylko $34 \%$ wartości dodanej brutto. Wynikałoby z tego, że przemysł bardzo silnie warunkuje tworzenie WDB. 


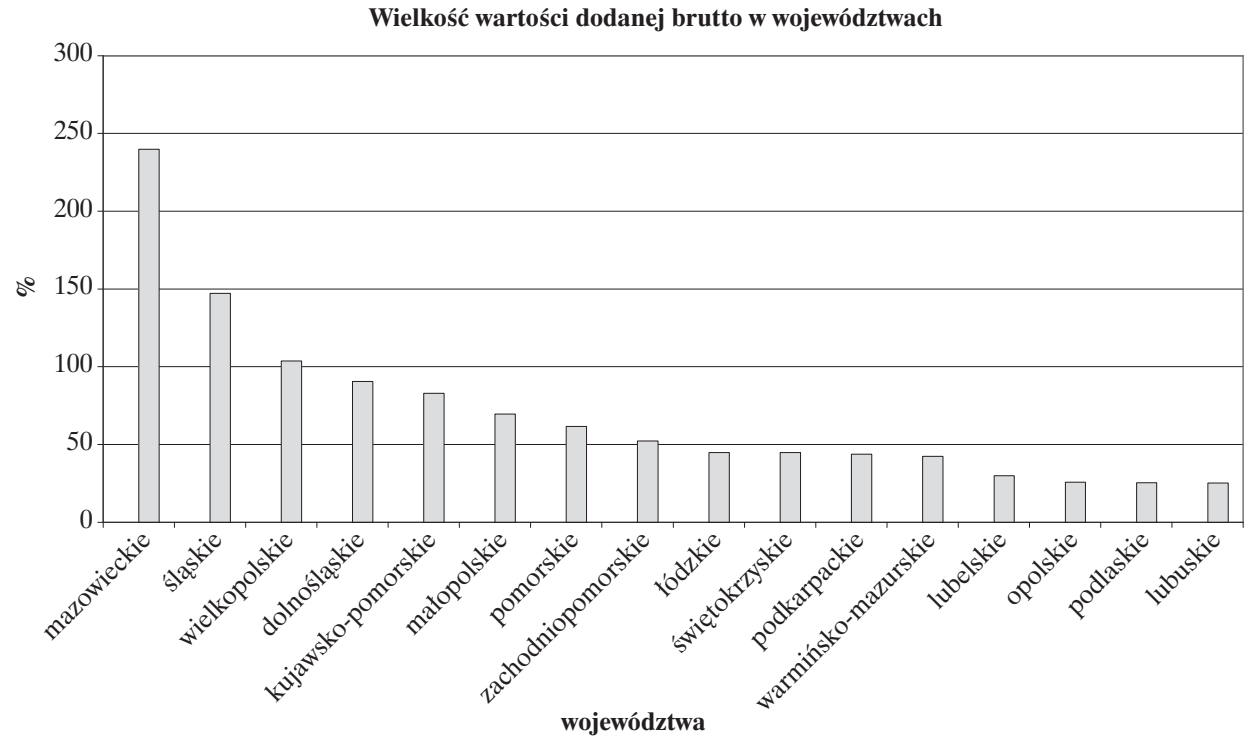

Źródło: opracowanie własne na podstawie Rocznika Statystycznego Województw 2010, GUS, Warszawa, 2010, II. Ważniejsze dane o województwach, s. 86-87.

Rysunek 3. Produktywność województw mierzona wartością dodaną brutto na 1 pracującego w 2008 roku (Polska=100)

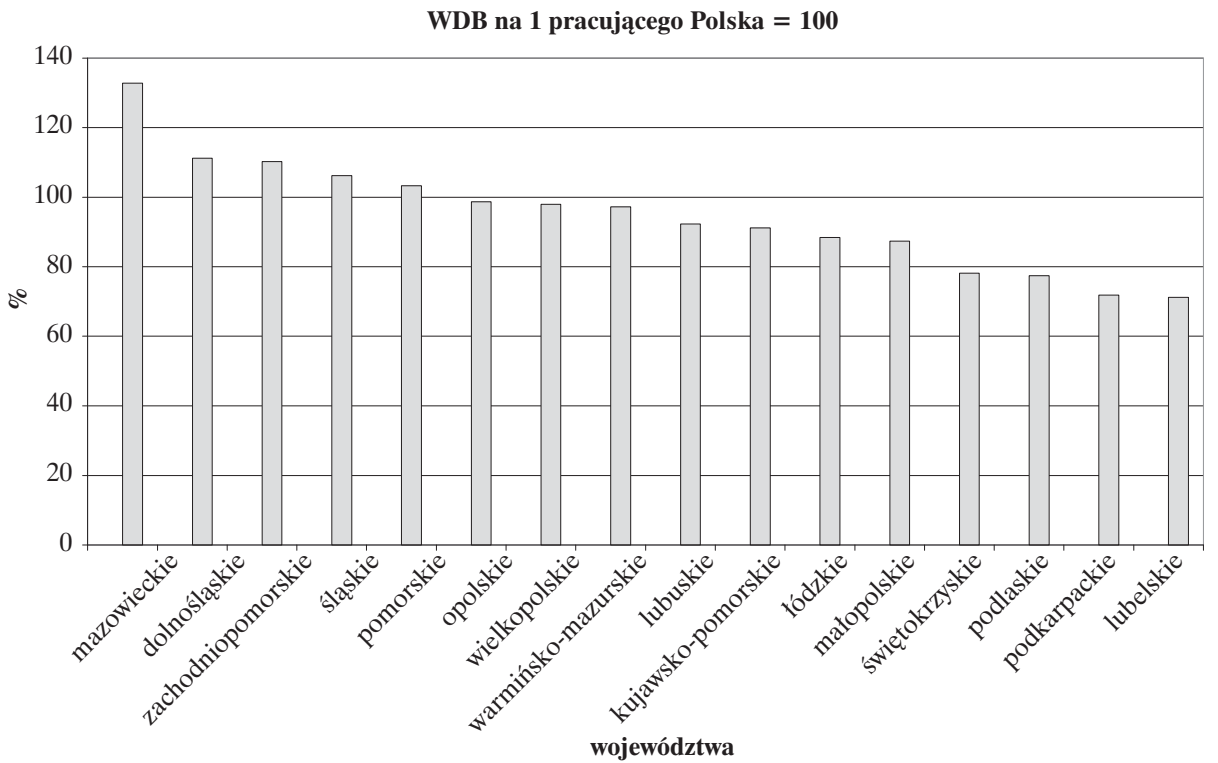

Źródło: opracowanie własne na podstawie Rocznika Statystycznego Województw 2010, GUS, Warszawa, 2010, II. Ważniejsze dane o województwach, s. 86-87.

Jednak oprócz wielkości WDB istotna jest także wydajność. Produktywność województw mierzona wartością dodaną brutto przypadającą na jednego mieszkańca w 2008 roku według województw prezentuje rysunek 3 . 
Najwyższą produktywność mierzoną wartością dodaną brutto na 1 pracującego tworzą województwa: mazowieckie, dolnośląskie, śląskie i zachodniopomorskie, zaś najniższą: lubelskie, podkarpackie, podlaskie, świętokrzyskie.

Porównując wysokość wytwarzanego w województwach PKB per capita (tabela 2) oraz wysokość płac w niektórych regionach (tabela 3), można stwierdzić, że wysoka produktywność województw znajduje swoje odzwierciedlenie w wysokości płac, co jest racjonalne $\mathrm{z}$ ekonomicznego punktu widzenia.

W związku z powyższym powstają pytania:

- W jaki sposób doprowadzić do wzrostu produktywności $\mathrm{w}$ zaniedbanych pod tym względem województwach i regionach, mając na uwadze wzrost spójności gospodarczej?

- Jakie strukturalne bariery hamują wzrost produktywności w tych województwach?

Strukturę tworzenia wartości dodanej brutto w 2008 roku w Polsce przedstawia rysunek 4.

Z rysunku 4 wynika, iż najwyższe poziomy wartości dodanej brutto wytwarzane są w usługach, mniej w przemyśle, a najmniej w rolnictwie. Na podstawie rysunku 4 można także stwierdzić, że:

- najwięcej wartości dodanej brutto w sferze usług wytwarza się w województwach: mazowieckim, śląskim, wielkopolskim, małopolskim, dolnośląskim,

- na poziomie średnim dla Polski w województwach: łódzkim, pomorskim, kujawsko-pomorskim, zachodniopomorskim, lubelskim i podkarpackim, zaś

- najmniej w województwach: warmińskomazurskim, świętokrzyskim, podlaskim, lubuskim i opolskim.

Wartość dodana przemysłu także koncentruje się w pierwszych 7 województwach, przy czym najwięcej na Śląsku (w ujęciu geograficznym), bo w województwach śląskim i dolnośląskim (należących administracyjnie do dwóch różnych regionów) oraz na południu w województwie małopolskim. W regionie centralnym zaś - w województwach mazowieckim i łódzkim oraz w województwie wielkopolskim regionu północno-zachodniego.

Udział rolnictwa w tworzeniu WDB prezentuje rysunek 4A.

$\mathrm{Na}$ rysunku 4A zauważalny jest relatywnie wysoki udział rolnictwa w woje-

Rysunek 4. Struktura WDB w województwach w 2009 roku według rodzaju działalności i województw w podziale na rolnictwo, przemyst i usługi

Struktura WDB w województwach według usług

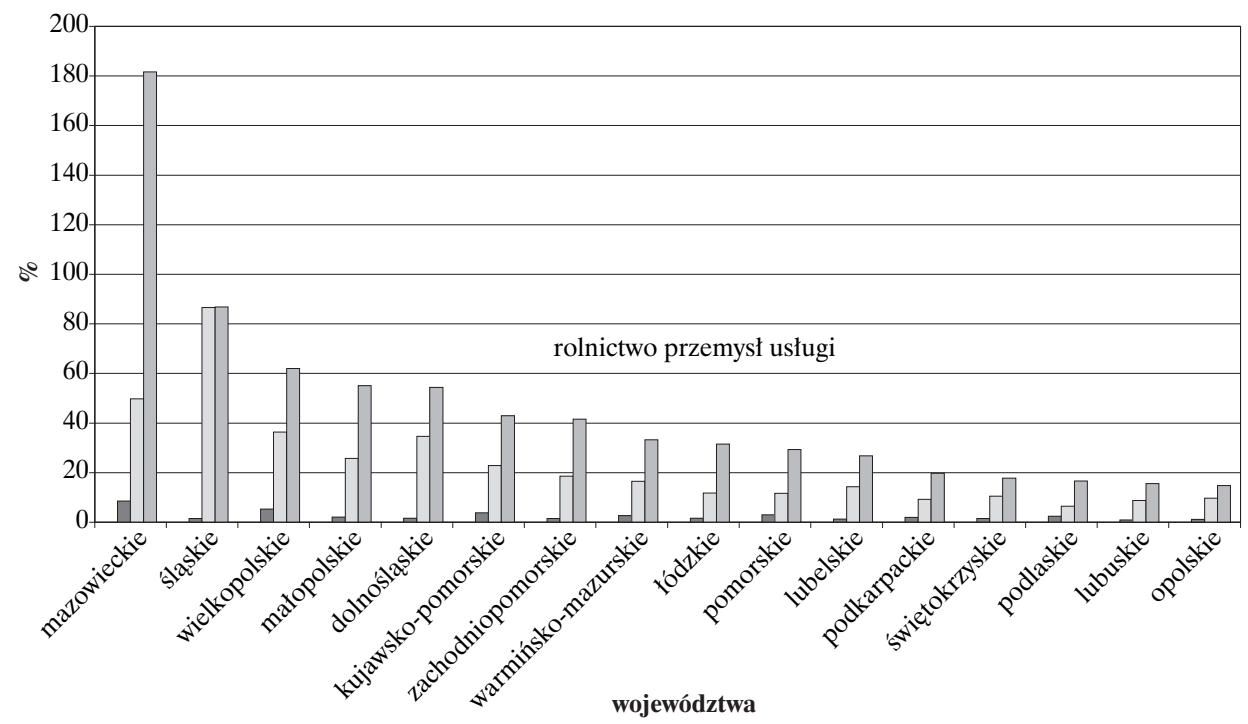

Źródło: opracowanie własne na podstawie Rocznika Statystycznego Województw 2010, GUS, Warszawa, 2010, II. Ważniejsze dane o województwach, s. 86-87. 


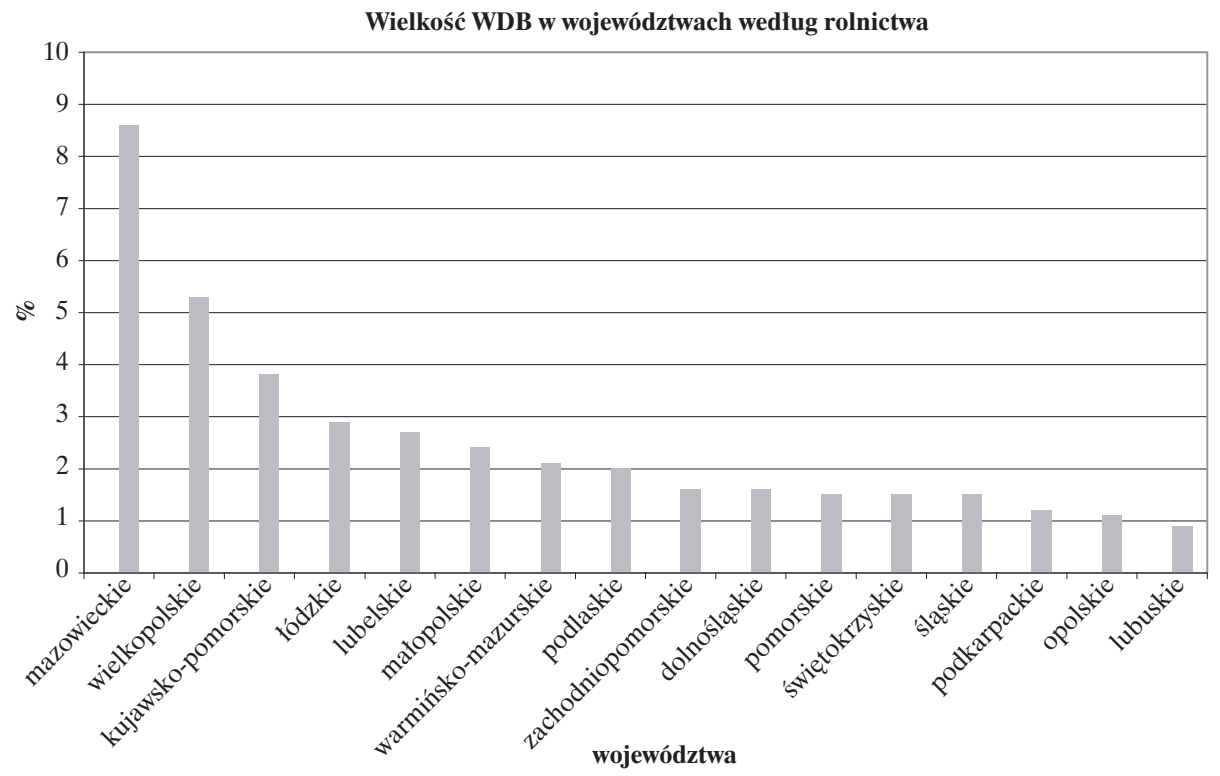

Źródło: opracowanie własne na podstawie Rocznika Statystycznego Województw 2010, GUS, Warszawa, 2010, II. Ważniejsze dane o województwach, s. 86-87.

wództwach: mazowieckim, wielkopolskim, łódzkim, lubelskim, kujawsko-pomorskim i podlaskim.

Wysoki rozwój rolnictwa w trzech pierwszych województwach łatwo wytłumaczyć typem rozwojowym na zasadzie centrumperyferie, gdzie aglomeracje miejskie zaopatrywane są w żywność $\mathrm{z}$ podregionów województwa. Jednak niepokojące są niskie udziały $\mathrm{w}$ tworzeniu WDB $\mathrm{w}$ rolnictwie w województwach takich jak: lubelskie, kujawsko-pomorskie, podlaskie, warmińsko-mazurskie, świętokrzyskie. Konieczna jest zatem większa specjalizacja produkcji rolniczej w typowo rolniczych województwach.

Na podstawie analizy rysunków 4 oraz 4A można odnieść błędne wrażenie, że rolnictwo jest mało dochodowe i należałoby wciąż ograniczać zatrudnienie w tym sektorze. Jest to jednak błędna interpretacja. O tym, jak bardzo błędne może być dążenie do upodobnienia struktur zatrudnienia w Polsce i w UE, może świadczyć wielkość rynku UE 27 na produkty przetwórstwa przemysłowego, oparte na rodzimym rolnictwie. Poza tym za rozwojem rolnictwa wolnego od produktów genetycznie modyfikowanych przemawia w Polsce relatywnie wysokie bezrobocie typu struk- turalnego oraz niski poziom zatrudnienia (zob. tabele 7 i 8 ).

Podsumowując rozważania na temat tworzenia wartości dodanej brutto w całej gospodarce, można stwierdzić, że w podziale trójsektorowym gospodarki na rolnictwo, przemysł i usługi najwyższe poziomy WDB wytwarzane są w usługach. Płynie z tego wniosek, iż należałoby w większym, niż dotychczas, stopniu rozwijać usługi, w tym także usługi wysoko zaawansowane technologicznie. Opinie różnych grup consultingowych przewidują w Polsce rozwój usług zaawansowanych technologicznie.

Jednak $\mathrm{z}$ niskiego udziału rolnictwa w tworzeniu WDB mógłby płynąć wniosek o dalszej redukcji strukturalnej sektora rolniczego w Polsce. I byłoby to błędne rozumowanie, jeżeli skonfrontujemy WDB w rolnictwie z tworzeniem wartości dodanej w UE oraz przewagami konkurencyjnymi Polski w ramach UE, co będzie przedmiotem dalszych rozważań.

\subsection{Miejsce Polski w strukturze tworzenia wartości dodanej Unii Europejskiej}

Miejsce Polski w tworzeniu wartości dodanej brutto i w zatrudnieniu sektora niefinansowego w 2008 roku odzwierciedla tabela 4. 
Tabela 4. Charakterystyka krajów UE 27 pod kątem tworzenia wartości dodanej i zatrudnienia w sektorze niefinansowym w 2008 roku

\begin{tabular}{|c|c|c|c|}
\hline Lp & Kraje UE 27 & 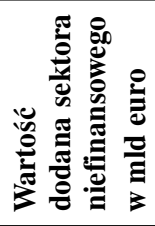 & 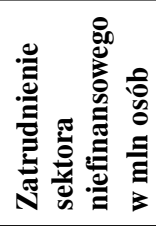 \\
\hline 1 & Niemcy & $1.252,4$ & 23,8 \\
\hline 2 & W. Brytania & $1.046,6$ & 18,4 \\
\hline 3 & Francja & 867,2 & b.d. \\
\hline 4 & Włochy & 673,8 & 16,0 \\
\hline 5 & Hiszpania & 557,0 & 13,5 \\
\hline 6 & Holandia & 297,4 & 5,5 \\
\hline 7 & Polska & 184,9 & 8,7 \\
\hline 8 & Szwecja & 175,1 & 2,9 \\
\hline 9 & Belgia & 166,8 & 2,5 \\
\hline 10 & Austria & 154,2 & 2,5 \\
\hline 11 & Dania & 120,5 & 2,0 \\
\hline 12 & Irlandia & 92,1 & 1,2 \\
\hline 13 & Czechy & 89,0 & 3,6 \\
\hline 14 & Finlandia & 88,2 & 1,4 \\
\hline 15 & Portugalia & 78,4 & 3,3 \\
\hline 16 & Rumunia & 58,8 & 4,4 \\
\hline 17 & Węgry & 51,3 & 2,6 \\
\hline 18 & Słowacja & 24,6 & 1,1 \\
\hline 19 & Luxemburg & 19,9 & 0,2 \\
\hline 20 & Słowenia & 19,4 & 0,6 \\
\hline 21 & Bułgaria & 18,0 & 2,0 \\
\hline 22 & Litwa & 12,9 & 0,9 \\
\hline 23 & Lotwa & 10,7 & 0,6 \\
\hline 24 & Cypr & 9,3 & 0,2 \\
\hline 25 & Grecja & 8,3 & 0,4 \\
\hline 26 & Estonia & b.d & b.d. \\
\hline 27 & Malta & b.d. & b.d. \\
\hline & Razem UE 27 & $6.155,7$ & 136,2 \\
\hline
\end{tabular}

Źródło: opracowanie własne na podstawie Table 2.3 Key indicators for the non-financial business economy, 2008 in: European business: Facts and Figures, Eurostat, 2009.

$\mathrm{Na}$ podstawie danych zawartych $\mathrm{w}$ tabeli 4 można zauważyć, że Polska znajduje się na siódmym miejscu w wytwarzaniu wartości dodanej szeroko rozumianego sektora produkcji przemysłowej (sektora niefinansowego) oraz szóstym miejscu pod względem liczby zatrudnionych tam osób. Jednakże wielkość zatrudnienia często nie determinuje wysokości osiąganej wartości dodanej, co wynika z różnic produktywności. Na przykład 4,4 mln osób w Rumunii wytwarza 58,8 mld euro wartości dodanej, natomiast na Węgrzech prawie połowa mniej, bo 2,6 mln osób wytwarza podobny poziom wartości dodanej wynoszący 51,3 mld euro.

\subsection{Specjalizacje gospodarki Polski w UE}

Gospodarka Polski wypracowała także przewagi konkurencyjne w ramach UE 27, ponieważ nasz kraj znalazł się wśród najbardziej wyspecjalizowanych producentów dóbr.

Spośród 24 podstawowych sekcji produkcji w UE, takich jak produkcja: wyposażenia transportowego, maszyn elektrycznych i sprzętu optycznego, dostarczanie elektryczności, gazu, wyrobów niemetalowych, tekstyliów, produkcja wyrobów metalowych recykling i dostarczanie wody itd. Polska znalazła przewagę komparatywną tylko jako najbardziej wyspecjalizowany producent żywności i napojów oraz drugi po najbardziej wyspecjalizowanym producencie wyrobów chemicznych. Warto dodać, że w przypadku około połowy wymienionych z 24 sekcji produkcji największym producentem są Niemcy, zaś około połowy kolejnych dziedzin produkcji - Anglia.

Konfrontacja specjalizacji Polski w produkcji artykułów żywnościowych i napojów koresponduje $\mathrm{z}$ sektorową strukturą produkcji przemysłowej UE 27, co odzwierciedla tabela 6 .

Jak wynika $\mathrm{z}$ danych zawartych $\mathrm{w}$ tabeli 6 , towary o największych udziałach w rynku unijnym to produkty metalowe i żywnościowe, w których produkcji specjalizuje się Polska. Być może jest to powód relatywnie szybkiego tempa wzrostu polskiej gospodarki na tle innych krajów UE i to mimo kryzysu lat 2008-2011.

A zatem Polska znalazła w UE przewagi komparatywne i była najbardziej wyspecjalizowanym krajem w 2006 roku w produkcji żywności napojów i drugim po najbardziej wyspecjalizowanym kraju w produkcji wyrobów metalowych i dostarczaniu ogrzewania (tabela 6). Jednocześnie obie sekcje wytwórczości: produkty metalowe i produkty żywnościowe zajmują w UE 27 $20 \%$ udziału w tworzeniu wartości dodanej (tabela 7).

Podsumowując rozważania na temat tworzenia wartości dodanej brutto w trójsektorowym podziale gospodarki, można 
Tabela 5. Najwięksi bądź najbardziej wyspecjalizowani producenci dóbr w UE 27 w 2006 roku (na podstawie relacji wartości dodanej określonej sekcji w danym kraju do wartości dodanej tej sekcji w UE 27)

\begin{tabular}{|l|l|l|l|l|}
\hline \multicolumn{1}{|c|}{$\begin{array}{c}\text { Sekcja } \\
\text { Produkcji }\end{array}$} & $\begin{array}{c}\text { Największy } \\
\text { producent }\end{array}$ & $\begin{array}{c}\text { Drugi } \\
\text { po największym } \\
\text { producencie }\end{array}$ & $\begin{array}{c}\text { Najbardziej } \\
\text { wyspecjalizowany }\end{array}$ & $\begin{array}{c}\text { Drugi } \\
\text { po najbardziej } \\
\text { wyspecjaliz. }\end{array}$ \\
\hline Żywność, napoje, tytoń & Niemcy & Anglia & Polska & Irlandia \\
\hline $\begin{array}{l}\text { Dostarczanie ogrzewania, } \\
\text { Produkty chemiczne }\end{array}$ & Niemcy & Francja & Belgia & Polska \\
\hline
\end{tabular}

Źródło: opracowanie własne na podstawie Table 1.3 Largest and most specialized Member States in: European Business. Facts and Figures, EU, Eurostat, 2009, s. 23.

Tabela 6. Struktura wartości dodanej największych sektorów produkcji przemysłowej UE 27 w 2008 roku (wartość dodana UE $27=100$ )

\begin{tabular}{|l|c|}
\hline \multicolumn{1}{|c|}{ Sektor produkcji przemysłowej } & $\begin{array}{c}\text { Procentowy udzial danego sektora } \\
\text { w wartości dodanej } \\
\text { UE 27 = 100 }\end{array}$ \\
\hline 1. Produkty metalowe & 10,0 \\
2. Produkty żywnościowe & 10,0 \\
3. Urządzenia elektryczne & 5,0 \\
4. Komputery, produkty elektroniczne i optyczne & 5,0 \\
5. Wyroby z plastiku & 5,0 \\
\hline Razem & 35,0 \\
\hline
\end{tabular}

Źródło: opracowanie własne na podstawie Figure 3.3. Sectoral analysis, manufacturing EU 27, 2008, value added, European Business: Facts and Figures, Eurostat, 2009.

zauważyć, że najwyższe poziomy WDB wytwarzane są w usługach, następnie przemyśle, a najniższe w rolnictwie. Mógłby z tego wynikać błędny wniosek, że należy ograniczyć się do rozwoju usług, bo przynosi najwyższe poziomy WDB. Jednak wiele przedsiębiorstw usługowych pracuje na rzecz przemysłu, który jest źródłem powiązań usługowo-produkcyjnych.

Najniższe poziomy WDB osiagane w rolnictwie stanowią jednak źródło przewagi konkurencyjnej w UE 27. Okazuje się, iż na produkty żywnościowe i metalowe, w produkcji których wyspecjalizowała się w 2006 roku Polska, istnieje aż $20 \%$ udział w całym rynku UE 27. A zatem można wnioskować, że nastąpi dalszy rozwój rolnictwa, jednak powstaje pytanie, czy będzie to rolnictwo zaawansowane technologicznie, czy bardziej pracochłonne, „ekologiczne”, wolne od nadmiaru pestycydów i genetycznych modyfikacji. W celu rozwikłania tego problemu poniżej przedstawiona została charakterystyka zasobów pracy w podziale na województwa.

\subsection{Zasoby pracy $w$ województwach Polski na tle bezrobocia strukturalnego w UE 27}

Na podstawie tabeli 7 można stwierdzić, że w Polsce w 2009 roku było 25,1 mln osób w wieku produkcyjnym, z czego $13,4 \mathrm{mln}$ osób to pracujący, co oznacza, że 11,6 mln osób w wieku produkcyjnym nie pracowało.

Jeżeli weźmiemy pod uwagę bezrobotnych zarejestrowanych i odejmiemy tę liczbę od ludności w wieku produkcyjnym, to otrzymujemy $9,3 \mathrm{mln}(11.777,9-1.3449,1)$ osób w wieku produkcyjnym, które nie pracują i nie mają statusu osób bezrobotnych. Zatem około $10 \mathrm{mln}$ ludzi nie pracowało i nie było osobami bezrobotnymi. Istnieją więc niewykorzystane zasoby osób w wieku produkcyjnym.

Odsetki stóp zatrudnienia w województwach wskazują, że najwyższy poziom zatrudnienia występuje w województwie mazowieckim.

Stopy zatrudnienia wyższe niż przeciętna dla Polski występowały (oprócz wymienionego wcześniej mazowieckiego) w woje- 
Tabela 7. Ludność w wieku produkcyjnym, zatrudnieni, bezrobotni, stopa zatrudnienia, stopa bezrobocia, (osoby nieaktywne zawodowo) według regionów i województw w 2009 roku

\begin{tabular}{|l|c|c|c|c|c|c|}
\hline Województwo & $\begin{array}{c}\text { Ludność } \\
\text { w wieku } \\
\text { produkc. } \\
\text { w tys. } \\
\text { [L] }\end{array}$ & $\begin{array}{c}\text { Pracujący } \\
\text { w tys. }\end{array}$ & $\begin{array}{c}\text { Bezrobotni } \\
\text { zarejestr. } \\
\text { w tys. }\end{array}$ & $\begin{array}{c}\text { Stopa } \\
\text { zatrudn. } \\
\text { w \% }\end{array}$ & $\begin{array}{c}\text { Stopa } \\
\text { bezrobocia } \\
\text { w \% }\end{array}$ & $\begin{array}{c}\text { Ludność } \\
\text { nie pracująca } \\
\text { w wieku }\end{array}$ \\
Mrodukcyjnym \\
Mazowieckie & 3312,4 & 2256,7 & 224,5 & 68,12 & 9,0 & 1055,7 \\
[ódzkie & 1597,5 & 937,4 & 128,1 & 58,68 & 11,9 & 660,1 \\
\hline Małopolskie & 2038,4 & 1121,0 & 130,0 & 54,99 & 9,7 & 917,4 \\
Śląskie & 3008,4 & 1592,7 & 168,4 & 52,94 & 9,4 & 1415,7 \\
\hline Lubelskie & 2325,1 & 759,5 & 117,2 & 32,66 & 12,9 & 1565,6 \\
Podkarpackie & 1339,8 & 667,3 & 141,9 & 49,80 & 15,9 & 672,5 \\
Podlaskie & 697,4 & 409,0 & 61,2 & 58,64 & 12,8 & 288,4 \\
Świętokrzyskie & 762,0 & 451,7 & 83,8 & 59,27 & 15,1 & 310,3 \\
\hline Kuj.-pomorskie & 1294,0 & 686,6 & 134,1 & 53,06 & 16,2 & 607,4 \\
Pomorskie & 1419,0 & 736,8 & 100,3 & 51,92 & 11,9 & 682,2 \\
Warm.-mazur. & 912,8 & 412,0 & 109,2 & 45,13 & 20,7 & 500,8 \\
\hline Dolnośląskie & 1842,4 & 980,5 & 146,3 & 53,21 & 12,8 & 861,9 \\
Oppolskie & 657,0 & 310,2 & 47,1 & 47,21 & 12,9 & 346,8 \\
\hline Lubuskie & 658,0 & 309,4 & 61,1 & 47,02 & 16,2 & 348,6 \\
Wielkopolskie & 2210,0 & 1310,5 & 133,6 & 59,29 & 9,2 & 899,5 \\
Zachodniopom. & 1052,8 & 507,8 & 105,9 & 48,23 & 17,1 & 545,0 \\
\hline Razem & 24639,0 & 13449,1 & 1892,7 & 53,52 & 12,1 & 11677,9 \\
\hline
\end{tabular}

Źródło: opracowanie własne na podstawie Rocznika Statystycznego RP 2010, GUS, Warszawa 2011, tab. IV Ważniejsze dane o województwach.

wództwach: łódzkim, małopolskim, podlaskim, świętokrzyskim, kujawsko-pomorskim, dolnośląskim, wielkopolskim, natomiast w województwie śląskim i pomorskim były one lekko poniżej średniej krajowej.

Najniższa stopa zatrudnienia występowała w województwach: lubelskim, warmińsko-mazurskim, opolskim, lubuskim.

Najwyższe stopy bezrobocia wystąpiły w województwach: warmińsko-mazurskim, zachodniopomorskim, kujawsko-pomorskim, lubuskim i podkarpackim.

Najniższe stopy bezrobocia można wymienić w województwach: mazowieckim, wielkopolskim, śląskim, małopolskim.

Najwięcej osób niepracujących w wieku produkcyjnym można wymienić w województwie lubelskim - aż $1,5 \mathrm{mln}$; śląskim $-1,4$ mln oraz mazowieckim - 1,0 mln.

$\mathrm{Na}$ tym tle $\mathrm{w}$ tabeli 8 przedstawiono stopy bezrobocia strukturalnego $\mathrm{w}$ wybranych krajach UE 27.
Najwyższe stopy bezrobocia typu strukturalnego, według danych zawartych w tabeli 8 mają takie kraje jak: Hiszpania, Grecja i Irlandia oraz kraje posocjalistyczne: Estonia, Słowacja i Polska.

Hiszpania przystąpiła do UE wcześniej niż Polska, ale obydwa kraje przed przystąpieniem do UE miały podobne stopy bezrobocia w wysokości po $20 \%$ każdy. W ramach UE Hiszpania zdobyła przewage specjalizacyjną $\mathrm{w}$ nieruchomościach i ostatni kryzys z 2008 roku, który właśnie rozpoczął się w tej branży, spowodował bardzo niekorzystną sytuację Hiszpanii. Jednak stopa bezrobocia strukturalnego wskazuje, że ani Hiszpania, ani Polska nie rozwiązały problemu bezrobocia strukturalnego od momentu wejścia do UE. W czasie kryzysu sytuacja Polski jest relatywnie korzystniejsza, ponieważ Polska specjalizuje się, między innymi, w produkcji żywności, napojów, produk- 


\begin{tabular}{|l|l|c|r|r|r|r|r|r|}
\hline \multirow{2}{*}{ Kraje } & \multirow{2}{*}{$\begin{array}{l}\text { Nazwa } \\
\text { krajua }^{\mathbf{b}}\end{array}$} & \multicolumn{7}{|c|}{ Stopy bezrobocia strukturalnego } \\
\cline { 3 - 9 } & & $\begin{array}{c}\text { Przeciętna } \\
\mathbf{1 9 9 6 - 2 0 0 5}\end{array}$ & $\mathbf{2 0 0 7}$ & $\mathbf{2 0 0 8}$ & $\mathbf{2 0 0 9}$ & $\mathbf{2 0 1 0}$ & $\mathbf{2 0 1 1}$ & $\mathbf{2 0 1 2}^{\mathbf{a}}$ \\
\hline O najwyższym & Hiszpania & 12,0 & 8,9 & 9,5 & 11,1 & 12,7 & 13,5 & 13,8 \\
poziomie & Estonia & 10,1 & 10,1 & 10,4 & 11,0 & 11,9 & 12,2 & 12,1 \\
bezrobocia & Słowacja & 15,9 & 13,4 & 12,5 & 11,9 & 11,4 & 11,3 & 11,3 \\
strukturalnego & Grecja & 9,4 & 8,9 & 8,9 & 9,1 & 9,9 & 10,8 & 11,2 \\
& Polska & 14,5 & 11,4 & 9,8 & 9,4 & 9,5 & 9,5 & 9,5 \\
& Irlandia & 7,0 & 4,7 & 5,1 & 6,8 & 8,0 & 8,8 & 9,2 \\
\hline O najniższym & Holandia & 4,3 & 3,8 & 3,7 & 3,7 & 3,7 & 3,7 & 3,7 \\
poziomie b.s. & Austria & 4,0 & 4,3 & 4,3 & 4,3 & 4,3 & 4,3 & 4,3 \\
\hline
\end{tabular}

a - prognoza na 2012 rok

b - brak danych dotyczących Bułgarii, Cypru, Litwy, Łotwy, Malty, Rumunii

Źródło: opracowanie własne na podstawie Table 22 Structural unemployment and unit labor costs (NAIRU), OECD Economic Outlook Volume 2011, Issue 1 - No. 89 OECD 2011; www.oecd.org (06.06.2011).

tach chemicznych, a więc produkcji dóbr relatywnie „odpornych” na sytuację kryzysową. Jednak to nie umniejsza problemu makroekonomicznego, jakim jest bezrobocie typu strukturalnego, niezwykle uciążliwego do zlikwidowania.

Podsumowując rozważania z części drugiej opracowania można wnioskować o przyjęcie strategii wzrostu zatrudnienia $\mathrm{w}$ ekologicznie czystym rolnictwie, które dawałoby przewagę konkurencyjna w Europie i Stanach Zjednoczonych. Na takie rozwiązanie wskazuje nie tylko specjalizacja naszego kraju i 10\% rynek unijny, ale także znaczne zasoby ludzkie w wieku produkcyjnym, które nie pracują oraz bezrobocie i niski poziom zatrudnienia. Jeżeli do tego jeszcze dodać innowacyjność w sferze dystrybucji świeżej żywności z jej marketingiem międzynarodowym, to jest to kierunek, który mógłby w znacznej mierze przyczynić się do wzrostu stopy zatrudnienia i osiągnięcia założeń strategii Europa 2020 na lata 2014-2020.

Innowacyjność wiąże się jednak nie tylko $\mathrm{z}$ wykorzystaniem funduszy europejskich na ten cel, ale i wzrostem nakładów na $\mathrm{B}+\mathrm{R}$. Ambitne plany UE zakładają wzrost nakładów na tę sferę do poziomu powyżej 3\% PKB. W sytuacji Polski, przy wskaźniku $0,6 \%$ nakładów na $\mathrm{B}+\mathrm{R}$, jest to niezwykle trudne zadanie do osiągnięcia, nie tylko ze względu na samą wysokość nakładów, ale również ich strukturę.

\subsection{Struktura nakładów na $B+R$ według województw}

Wprawdzie w Polsce nakłady na $\mathrm{B}+\mathrm{R}$ są dość niskie, bo od wielu lat oscylują wokół poziomu $0,6 \% \mathrm{PKB}$, to jednak najbardziej istotnym mankamentem tego sektora jest sposób finansowania; w Polsce gros wydatków na $\mathrm{B}+\mathrm{R}$ pochodzi $\mathrm{z}$ nakładów publicznych. W krajach wysoko rozwiniętych gros wydatków na $\mathrm{B}+\mathrm{R}$ pochodzi ze źródeł prywatnych. Mimo iż sektor $\mathrm{B}+\mathrm{R}$ w Polsce jest liczący w Europie, to jednak głównym jego mankamentem jest sposób finansowania, a właściwie brak prywatnego sektora $B+R$. Podstawowym problemem w tym zakresie jest zatem tworzenie podstaw rynku wdrożeń w Polsce.

Bieżącą sytuację w zakresie podziału nakładów publicznych na województwa ilustruje tabela 9.

$\mathrm{Na}$ szczeblu regionalnym największe nakłady na $\mathrm{B}+\mathrm{R}$ występują $\mathrm{w}$ regionie centralnym $(44 \%)$, następnie południowym $(20,9 \%)$ oraz północno-zachodnim $(10,9 \%)$. Na pozostałe trzy regiony przypada łącznie $24,3 \%$ ogółu nakładów na ten cel. Na szczeblu wojewódzkim nierównomierność nakładów na $B+R$ jest jeszcze większa. I tak, w obrębie regionu centralnego na województwo mazowieckie przypada 38,6\% ogółu nakładów, a na drugie województwo tego regionu - łódzkie tylko 5,4\% tychże nakładów. Bardziej równomierny podział nakładów zaznacza się 
Tabela 9. Struktura nakładów na $B+R$ według regionów $i$ województw w 2009 roku w cenach bieżących i w relacji do $P K B$

\begin{tabular}{|c|c|c|c|c|c|c|}
\hline \multicolumn{3}{|c|}{ R E G I O N } & \multicolumn{4}{|c|}{ WO J E W Ó D Z T WO } \\
\hline \multirow[b]{2}{*}{ Nazwa } & \multicolumn{2}{|c|}{ Nakłady na $B+R$} & \multirow[b]{2}{*}{ Nazwa } & \multicolumn{3}{|c|}{ Nakłady na $B+R$} \\
\hline & w mld zl & $\begin{array}{c}\text { Strukt. } \\
\text { w \% }\end{array}$ & & w mld zl & $\begin{array}{c}\text { Strukt. } \\
\text { w } \%\end{array}$ & $\begin{array}{c}\text { w relacji } \\
\text { do PKB } \\
\text { w } \%\end{array}$ \\
\hline \multirow[t]{2}{*}{ Centralny } & 3991,1 & 44,0 & Łódzkie & 492,9 & 5,4 & 0,54 \\
\hline & & & Mazowieckie & $3.498,2$ & 38,6 & 1,21 \\
\hline \multirow[t]{2}{*}{ Południowy } & 1879,3 & 20,7 & Małopolskie & 922,7 & 10,2 & 0,95 \\
\hline & & & Śląskie & 956,6 & 10,5 & 0,36 \\
\hline \multirow[t]{4}{*}{ Wschodni } & 698,0 & 7,7 & Lubelskie & 295,9 & 3,3 & 0,48 \\
\hline & & & Podkarpackie & 189,0 & 2,1 & 0,37 \\
\hline & & & Podlaskie & 66,4 & 0,7 & 0,26 \\
\hline & & & Świętokrzyskie & 146,7 & 1,6 & 0,27 \\
\hline \multirow[t]{3}{*}{ Północno-Zachodni } & 992,7 & 10,9 & Lubuskie & 29,0 & 0,4 & 0,10 \\
\hline & & & Wielkopolskie & 845,9 & 9,3 & 0,52 \\
\hline & & & Zachodniopomorskie & 117,8 & 1,3 & 0,24 \\
\hline \multirow[t]{2}{*}{ Południowo-Zachodni } & 649,9 & 7,2 & Dolnośląskie & 581,4 & 6,4 & 0,44 \\
\hline & & & Opolskie & 68,5 & 0,8 & 0,14 \\
\hline \multirow[t]{3}{*}{ Północny } & 859,0 & 9,4 & Kujawsko-pomorskie & 345,9 & 3,8 & 0,22 \\
\hline & & & Pomorskie & 397,5 & 4,4 & 0,57 \\
\hline & & & Warmińsko-mazurskie & 115,6 & 1,2 & 0,23 \\
\hline Razem & 9070,0 & 100,0 & Polska & $9.070,0$ & 100,0 & 0,60 \\
\hline
\end{tabular}

Źródło: opracowanie własne na podstawie Rocznik Statystyczny RP 2010, GUS, Warszawa, 2010, tabela IV Ważniejsze dane o województwach w 2009 roku, s. 86-89.

w regionie południowym między województwa: śląskie i małopolskie, każde powyżej $10 \%$. Zróżnicowanie wysokości nakładów w pozostałych województwach jest znaczne. Do województw o najniższych poziomach nakładów na $\mathrm{B}+\mathrm{R}$ należa: lubuskie, podlaskie, opolskie, warmińsko-mazurskie, zachodniopomorskie, świętokrzyskie.

Biorąc pod uwage niski poziom nakładów na $\mathrm{B}+\mathrm{R}$ w Polsce, znaczną dyspersję nakładów między najbogatsze miasta i pozostałe tereny, można mieć wątpliwości co do możliwości rozwoju regionów nieaktywnych gospodarczo. Właśnie tereny słabo rozwinięte potrzebują wsparcia zaplecza $B+R$ dla określenia specjalizacji rozwojowych. W kontekście niewykorzystanych zasobów ludzkich w Polsce dobrze, aby to były specjalizacje pracochłonne aż do momentu wchłonięcia nadwyżek siły roboczej.

\section{Podsumowanie}

Rozwój regionalny w Polsce nie jest ani spójny, ani zrównoważony. Najwyższym tempem rozwoju w Polsce charakteryzują się obszary większych aglomeracji miejskich: Warszawy, Łodzi, Katowic, Krakowa, Poznania, Gdańska, Wrocławia i Szczecina, przy czym rozwój Warszawy jest kilkakrotnie wyższy od pozostałych miast.

W związku z tym wyzwaniem gospodarczym staje się aktywizacja terenów poza większymi miastami.

Dywergencja dochodowa jest w sposób szczególny zauważalna $\mathrm{w}$ podregionach. Potwierdzają ją różnice płacowe. 
Najwyższy wzrost, mierzony wartością dodaną brutto, wytwarzany jest w usługach, mniej w przemyśle, a najmniej w rolnictwie. Można także stwierdzić, że:

- najwięcej wartości dodanej brutto w sferze usług wytwarza się w województwach: mazowieckim, śląskim, wielkopolskim, małopolskim, dolnośląskim,

- na poziomie średnim dla Polski w województwach: łódzkim, pomorskim, kujawsko-pomorskim, zachodniopomorskim, lubelskim i podkarpackim, zaś

- najmniej w województwach: warmińskomazurskim, świętokrzyskim, podlaskim, lubuskim i opolskim.

Wartość dodana przemysłu koncentruje się w 7 województwach: mazowieckim, śląskim, dolnośląskim, wielkopolskim, małopolskim, łódzkim i pomorskim.

Najniższy poziom WDB wytwarzany jest w rolnictwie. Jednak opierając się na rodzimym rolnictwie, Polska znalazła w UE przewagi komparatywne i była najbardziej wyspecjalizowanym krajem w 2006 roku w produkcji żywności i napojów oraz drugim po najbardziej wyspecjalizowanym kraju w produkcji wyrobów metalowych i dostarczaniu ogrzewania (tabela 6). Jednocześnie obie sekcje wytwórczości - produkty metalowe i produkty żywnościowe zajmują w UE $2720 \%$ udziału w tworzeniu wartości dodanej (tabela 6).

W 2009 roku w Polsce było 25,1 mln osób w wieku produkcyjnym, z czego 13,4 mln osób to pracujący, co oznacza, że 11,6 mln osób w wieku produkcyjnym nie pracowało.

Odsetki stóp zatrudnienia w województwach wskazują, iż najwyższy poziom zatrudnienia występuje w województwie mazowieckim.

Stopy zatrudnienia wyższe niż przeciętna dla Polski występowały (oprócz wymienionego wcześniej mazowieckiego) w województwach: łódzkim, małopolskim, podlaskim, świętokrzyskim, kujawskopomorskim, dolnośląskim, wielkopolskim, natomiast w województwach śląskim i pomorskim lekko poniżej średniej krajowej.

Najniższa stopa zatrudnienia występowała w województwach: lubelskim, warmińsko-mazurskim, opolskim, lubuskim.

Najwyższe stopy bezrobocia wystąpiły w województwach: warmińsko-mazurskim, zachodniopomorskim, kujawsko-pomorskim, lubuskim i podkarpackim.
Najniższe stopy bezrobocia można wymienić w województwach: mazowieckim, wielkopolskim, śląskim, małopolskim.

Najwięcej osób niepracujących w wieku produkcyjnym można wymienić w województwie lubelskim - aż 1,5 mln; śląskim $-1,4$ mln oraz mazowieckim $-1,0$ mln.

W świetle przytoczonych danych powstaje wątpliwość, czy możliwy jest szybki wzrost wskaźnika zatrudnienia w Polsce i to do poziomu 75\% jako średniej krajowej, biorąc pod uwagę dane dotyczące aktualnych stóp zatrudnienia w województwach (por. tabela 7). Osiagnięcie tego celu UE na lata 2014-2020 wydaje się możliwe w Polsce pod warunkiem wyższego, niż dotychczas, poziomu inwestowania, uwarunkowanego przyznaniem relatywnie wysokich kwot pomocy dla Polski. Jeżeli byłyby to kwoty z funduszu spójności, to należy w większym stopniu uwzględnić zagospodarowanie wojewódzkich funduszy w celu zmniejszenia dysproporcji dochodowych i płacowych na korzyść większej spójności.

Podsumowując rozważania, można wnioskować o przyjęcie strategii wzrostu zatrudnienia w ekologicznie czystym rolnictwie, które dawałoby przewagę konkurencyjną w Europie i Stanach Zjednoczonych. $\mathrm{Na}$ takie rozwiązanie wskazuje nie tylko specjalizacja naszego kraju i $10 \%$ rynek unijny, ale także znaczne zasoby ludzkie w wieku produkcyjnym, które nie pracują, oraz bezrobocie i niski poziom zatrudnienia. Jeżeli do tego jeszcze dodać innowacyjność w sferze dystrybucji świeżej żywności $\mathrm{z}$ jej marketingiem międzynarodowym, to jest to kierunek, który mógłby w znacznej mierze przyczynić się do wzrostu stopy zatrudnienia i osiągnięcia założeń strategii Europa 2020 na lata 2014-2020.

Jednakże innowacyjność wiąże się nie tylko z wykorzystaniem funduszy europejskich na ten cel, ale i wzrostem nakładów na $\mathrm{B}+\mathrm{R}$. Ambitne plany UE zakładają wzrost nakładów na tę sferę do poziomu powyżej $3 \%$ PKB. W sytuacji Polski, przy wskaźniku $0,6 \%$ nakładów na $B+R$ jest to niezwykle trudne zadanie do osiaggnięcia nie tylko ze względu na samą wysokość nakładów, ale ich strukturę. Można uznać, iż dwa regiony: centralny i południowy koncentrują $64,7 \%$ nakładów na $\mathrm{B}+\mathrm{R}$, a na pozostałych 12 województw przypada 35,3\% tychże nakładów. Bez zwiększenia nakładów i ich efektywności na sferę $\mathrm{B}+\mathrm{R}$, a zwłaszcza bez 
zaangażowania prywatnych przedsiębiorstw w finansowanie prac wdrożeniowych, aktywizacja terenów nierozwiniętych będzie utrudniona. Obok specjalizacji rolniczych potrzebny jest dalszy rozwój usług, w tym także zaawansowanych technologicznie, które przynoszą najwyższe poziomy wartości dodanej brutto.

Na podstawie powyższej analizy można stwierdzić, że zagrożenia wewnętrzne rozwoju regionalnego są względnie rozpoznane, natomiast zagrożenia zewnętrzne są trudne do przewidzenia.

\section{Przypisy}

1 Dokument Europe 2020. A strategy for smart, sustainable and inclusive growth został przyjęty 3 marca 2010 przez Unię Europejską jako propozycja strategii na lata 2014-2020.

2 Trudności ze zdefiniowaniem wiedzy powodują, że nazwę gospodarki opartej na wiedzy należy traktować orientacyjnie.

3 I. Pietrzyk (2004) przestrzega przed nadmiernym upodabnianiem struktur, w tym struktury zatrudnienia, na korzyść różnic, z których można czerpać w wymianie między krajami.

\section{Bibliografia}

Armstrong, H. i Vickerman, R. (1995). Convergence and Divergence among European Regions. London: Pion.

Barca, F. (2009). An Agenda for a reformed Cohesion Policy. A place-based approach to meeting European Union challenges and expectation, Brussels: DG Regio, European Commission.

Barro, R.J. (1999). Inequality, Growth and Investment, Working Paper, 7038, NBER, March.

Barro, R.J. i Sala-i-Martn, X. (1995). Technological Diffusion, Convergence and Growth, Discussion Paper 1255. London.

Bolonek, R. (2009). Dywergencyjny charakter rozwoju regionalnego $w$ Polsce jako uwarunkowanie modernizacji gospodarki Polski, w: Nierówności społeczne, a wzrost gospodarczy. Problemy modernizacji Polski, Wydawnictwo Uniwersytetu Rzeszowskiego, Rzeszów.

Bywalec, Cz. (1996). Mezoekonomia i megaekonomia - nowe wymiary ekonomii, w: Rola mezoekonomii w rynkowym systemie zarządzania gospodarką. Księga jubileuszowa dla uczczenia 50-lecia pracy naukowo-dydaktycznej Profesora Józefa Gajdy, Akademia Ekonomiczna w Krakowie, Kraków.

„Europe 2020. A strategy for smart, sustainable and inclusive growth" dokument został przyjęty 3.03.2010 przez Unię Europejską jako propozycja strategii na lata 2014-2020.
European business: Facts and Figures (2009). Eurostat.

Frantzen, D. (2008). R\&D and manufacturing production specialization in developed economies, "Applied Economics", Vol. 40: 3009-3027.

Fujita, M., Krugman, P. i Venables, A. (1999). The spatial Economy: Cities, Regions, and International Trade. Cambridge, MA: MIT Press.

Gajda, J. (1996). Nowa rola mezoekonomii. W: Rola mezoekonomii $w$ rynkowym systemie zarzadzania gospodarka. Księga jubileuszowa dla uczczenia 50-lecia pracy naukowo-dydaktycznej Profesora Józefa Gajdy. Kraków: Akademia Ekonomiczna w Krakowie.

Gill, I. (2010). Regional development policies: placebased or people centred?, za: World Bank GIS Laboratory, 9.10.2010; http://www.voxeu.org/index. php?q=node/5644; dostęp 24.11.2011.

Glaeser, E.L. (red.). The new economics of urban and regional growth. w: Clark, G.L., Feldman, M.P., Gertler, M.S. (red.), The Oxford Handbook of Economic Geography. Oxford: Oxford University Press.

Gorynia, M. (1996). Wybrane aspekty teoretyczne mezoekonomii. W: Rola mezoekonomii $w$ rynkowym systemie zarzadzania gospodarka. Księga jubileuszowa dla uczczenia 50-lecia pracy naukowo-dydaktycznej Profesora Józefa Gajdy. Kraków: Akademia Ekonomiczna w Krakowie.

Grossman, G. i Helpman, E. (1991). Innovation and Growth In the Global Economy. Cambridge: MIT Press.

Jacobs, J. (1969). The Economy of Cities. New York: Random House.

Lucas, R. (1988). On the Mechanics of Economic Development. Journal of Monetary Economic, 22: 3-42

OECD (2011). Economic Outlook, 1(89). Pozyskane z: www.oecd.org (06.06.2011).

Orłowski, W. (2010). W pogoni za straconym czasem. Wrost gospodarczy w Europie Środkowo-Wschodniej 1950-2030. Warszawa: PWE.

Pietrzyk, I. (2004). Instytucjonalne uwarunkowania rozwoju gospodarczego. Prace Naukowe Akademii Ekonomicznej we Wroctawiu, 1024.

Pietrzyk, I. (2007). Wspólnotowa polityka spójności społeczno-gospodarczej w nowej perspektywie finansowej 2007-2013. W: Jewtuchowicz, A. (red.), Region w gospodarce opartej na wiedzy. Łódź: Wyd. Uniwersytetu Łódzkiego.

Porter, M.E. (1990/1998). The Competitive Advantage of Nations. New York: Free Press.

Roberts, M. i Setterfield, M. (2007). Endogenous regional Growth; A critical Survey. Centre for Economic and Public Policy, University of Cambridge, June 2007; www.landecon.cam.ac.uk/research/ reuag/ (05.06.2010). 
Rocznik Statystyczny RP 2010 (2011). Warszawa: GUS.

Rocznik Statystyczny Województw 2010 (2011). Warszawa: GUS.

Romer P.M. (1986). Increasing return and long-run Growth. Journal of Political Economy, 94: 1002-1037.

Song Hongbing (2010). Wojna o pieniadz. Prawdziwe źódła kryzysów finansowych. Bileany Wrocławskie: Wydawnictwo Wektory.
Weresa, M.A. (2010). Polska. Raport konkurencyjności. Klastry przemystowe a przewagi konkurencyjne. Warszawa: Oficyna Wydawnicza SGH.

Zioło, Z. (1996). Miejsce mezoekonomii w ekonomii. W: Rola mezoekonomii $w$ rynkowym systemie zarzqdzania gospodarkq. Ksiega jubileuszowa dla uczczenia 50-lecia pracy naukowo-dydaktycznej Profesora Józefa Gajdy. Kraków: Akademia Ekonomiczna w Krakowie. 